International Center for Agricultural Research

in the Dry Areas, Aleppo (Syria);

Lehrstuhl für Pflanzenbau und Pflanzenzüchtung,

Technische Universität Mïnchen, Freising-Weibenstephan (Germany, F.R.)

\title{
Performance and Variability of Local Barley Landraces in Near-Eastern Environments
}

\author{
E. WeItZIEN and G. FisChBECK
}

With 4 figures and 7 tables

Received April 11, 1989 / Accepted May 4, 1989

\begin{abstract}
Homozygous lines from six Syrian and two Jordanian landrace populations were tested under highly productive growing conditions in Tel Hadia (1982/ 83), under drought stress in Breda (1983/84), and under dryland salinity stress in Hegla $(1982 / 83 / 84)$ in Syria. Mean grain yield levels ranged between $260 \mathrm{~kg} / \mathrm{ha}$ and $4850 \mathrm{~kg} / \mathrm{ha}$. Under drought and salinity stress, the majority of the landrace lines outyielded the best checks significantly. In Tel Hadia the check cultivars mostly outyielded the landrace lines, but not always significantly. In all environments the harvest index of the landrace lines was near the optimum for barley. They expressed intermediate plant height and time to flowering, high lodging susceptibility under favorable growing conditions, high protein content, and a wide range of yield component combinations.

In the stress environments highly significant genetic variation among the landrace lines was found. The heritabilities for grain yield were high in these trials. The correlations between performance under stress and under favorable growing conditions were poor. Therefore, the largest gains for variety improvement for the Syrian steppe area are expected from direct selection under stress conditions.

Unique responses in proline accumulation and germination patterns in saline solution indicated specific adaptation in this material. These landraces, thus, are a useful source of breeding material, which also widens the genetic base of the present breeding program.
\end{abstract}

Key words: Hordeum vulgare - drought tolerance - salinity tolerance - field screening - landraces - germplasm - heritability - yield components proline - germination test

Barley production areas in the Eastern Mediterranean and the Near East are characterized by low and erratic winter rainfall, poor soil fertility, and low temperatures, with occasional frost during the tillering stage. The grain yield levels achieved by farmers are generally low ( $<1.0 \mathrm{t} / \mathrm{h}$ a, FAO, 1987). Straw yield is in many years an equally important commodity as grain yield. Barley production in Syria increased during the past 50 years mainly due to expansion of the area cultivated (WIRTH 1971). Thus large areas of steppe and grazing land with low yield potential are cultivated with barley.

The varieties used are all landraces (WELTZIEN 1988) and no new cultivars were available, which offered an economic advantage to the farmers of these areas, when this research was initiated. Variety improvement programs for low productivity environments have received little attention. This study was designed to test the usefulness of the local barley landraces as source material for the development of cultivars with a higher productivity in eastern 
mediterranean environments, receiving less than $250 \mathrm{~mm}$ annual rainfall. Therefore, we examined: 1 . the yield level of landrace lines in comparison to improved cultivars in several locations in northern Syria, 2. the genetic variation for yielding ability in this material, and 3 . specific stress responses of this material and check cultivars.

\section{Materials and Methods}

Genetic stocks: The landrace material used in these experiments was a set of 80 homozygous, homogenous lines, developed from single head progenies of the original collections (WELTZIEN 1982). These 80 lines represented eight populations, each collected from a farmer's field, from the major barley growing areas in Syria and Jordan (Fig. 1, Table 1). Except

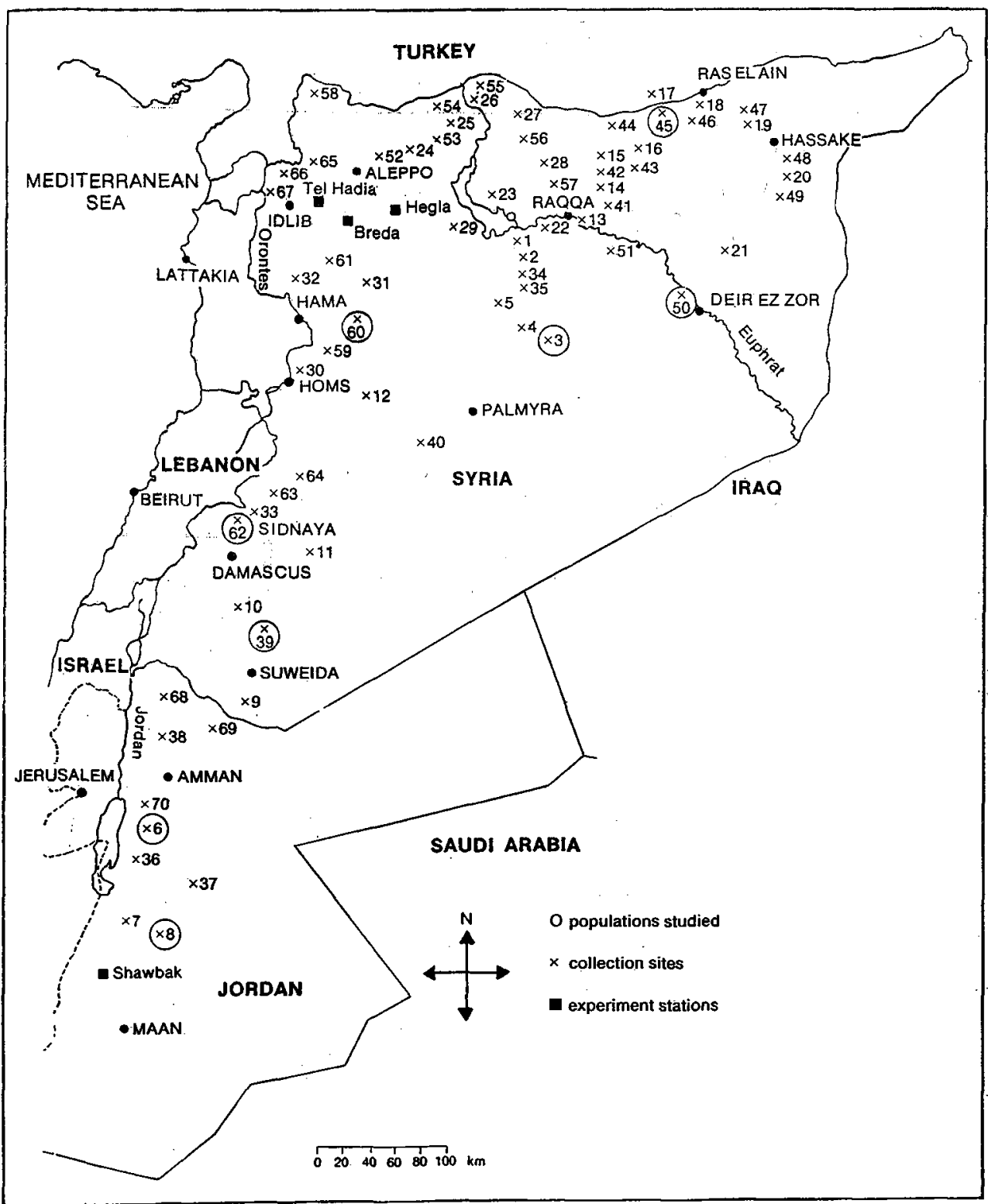

Fig. 1. Geographical origin of the landrace populations studied 
Table 1. Climatic characteristics of the places of origin of the landrace populations studied (ICARDA 1984, WALTER and LIETH 1969)

\begin{tabular}{rlrccc}
\hline $\begin{array}{l}\text { Pop. } \\
\text { (Fig. 1) }\end{array}$ & Population & ELB No.* & $\begin{array}{c}\text { Mean annual } \\
\text { rainfall }(\mathrm{mm})\end{array}$ & $\begin{array}{c}\text { Mean temp. } \\
\left({ }^{\circ} \mathrm{C}\right)\end{array}$ & $\begin{array}{c}\text { Elevation } \\
(\mathrm{m})\end{array}$ \\
\hline 6 & Madaba & $1-10$ & 400 & 19 & 900 \\
8 & Wadi el Hassa & $11-20$ & 160 & 19 & 820 \\
45 & Ras el Ain & $21-30$ & 300 & 18.5 & 400 \\
62 & Sidnaya & $31-40$ & 270 & - & 1350 \\
3 & At Taibe & $41-50$. & 135 & 19.1 & 470 \\
60 & Sheikh Ali & $51-60$ & 320 & 16.7 & 460 \\
50 & Deir es Zor & $61-70$ & 118 & 18.0 & 200 \\
39 & Um Zeitoun & $71-80$ & 380 & 15.5 & 860 \\
\hline
\end{tabular}

* The lines are being maintained at ICARDA, Genetic Resources Unit under these numbers.

for the population from Deir ez Zor, they were all two rowed. Ten randomly chosen lines were used from each of the eight populations. The checks Badia Beecher, six rowed, and ER/Apm, two rowed, represent superior lines identified by the barley breeding program at ICARDA Center in 1981. Arabic Abied, two rowed, is a representative of the Syrian landraces, found in the wetter parts of Syria. It has been multiplied at ICARDA center for several years. CM67 was used as a salt-tolerant check, which had shown some adaptation to eastern mediterranean growing conditions.

Testing procedures: In 1982/83 the 80 lines were grown at Tel Hadia, the main ICARDA research station, in an augmented design (FEDERER 1961) in 12 blocks with four checks each (Beecher, ER/Apm and Arabie Abied). The total rainfall during the growing season was $338 \mathrm{~mm}$. The predominant soil type is a Luvisol with an average $\mathrm{pH}$ of $6.9, \mathrm{C} / \mathrm{N}$ ratio of 8.9 and a depth varying between $80-120 \mathrm{~cm}$ (ICARDA 1981). $60 \mathrm{~kg} \mathrm{~N} / \mathrm{ha}$ and $80 \mathrm{~kg} \mathrm{P}_{2} \mathrm{O}_{5} / \mathrm{ha}$ were applied before planting. Weeds were controlled with an application of Brominal (1.5 l/ha) and Illoxan $(3.0 \mathrm{l} / \mathrm{ha})$. The seed rate was $100 \mathrm{~kg} / \mathrm{ha}$ in 6 row plots with $2.5 \mathrm{~m}$ length and $30 \mathrm{~cm}$ row spacing. All measurements were made on the central four rows, except for the harvest index which was measured on the border rows. Lodging susceptibility was scored on a $1-9$ scale, with 1 indicating a $100 \%$ standing plot crop, and a score of 9 a completely lodged plot.

The yield trial under drought conditions was planted in Breda in 1983/84, located $45 \mathrm{~km}$ SE of Aleppo. It received $220 \mathrm{~mm}$ rainfall during the growing season. The soil type is a Calcic xerosol with increasing gypsum content below $70 \mathrm{~cm}$ soil depth. $80 \mathrm{~kg}$ of ammonium phosphate were applied before planting. 78 of the landrace lines and two checks, Badia and ER/Apm, were planted in a randomized complete block design with three replica- tions. Each plot had eight rows of $2.5 \mathrm{~m}$ length, at $20 \mathrm{~cm}$ spacings. The center six rows were harvested $\left(3.0 \mathrm{~m}^{2}\right)$.

Field tests under saline conditions were planted in Hegla, located $50 \mathrm{~km}$ East of Aleppo in 1982/83 and $1983 / 84$. The rainfall received in these two seasons was $219 \mathrm{~mm}$ and $131 \mathrm{~mm}$ respectively. The soil type is calcic xerosol with average $\mathrm{pH}$ of $8.2 ; 8.5 \%$ organic matter and $44.7 \% \mathrm{CaCO}_{3}$ in the top $20 \mathrm{~cm}$. $80 \mathrm{~kg}$ ammonium phosphate were applied before planting. The soil conductivity in the top $40 \mathrm{~cm}$ varied along a slight elevation gradient between 1.4 and $15.9 \mathrm{~ms} \mathrm{~cm}^{-1}$ in $1982 / 83$ and 5.5 and $15.0 \mathrm{ds} \mathrm{m}^{-1}$ in 1983/84, measured during the tillering phase as 1 : 1 water extracts. Seasonal changes of soil conductivity were monitored in 1983 with sensors (Soilmoisture, St. Barbara Type 3000A) in five soil depths. Salinity levels increased sharply in deeper soil layers, and in the top $30 \mathrm{~cm}$, as temperatures rose and rainfall ceased (WELTZIEN 1986). The predominant salt was $\mathrm{NaCl}$, but sulfate and hydrogenous carbonate were also found.

The experiments were laid out as randomized complete blocks with eight replications. The replications were distributed across the salinity gradient. Soil variability within each replication was further minimized by reducing the plot size to one $1 \mathrm{~m}$ row at a spacing of $20 \mathrm{~cm}$. Each group of four test plots was bordered by a check row on each side, using ER/ Apm and CM67 alternately. In 1983/84 only three of the eight replications could be harvested, due to poor stand establishment in the more saline areas. In 1984 we irrigated three times during late tillering and booting stages, applying a total of $30 \mathrm{~mm}$.

Proline analysis: In 1984 green flag leaves of seven lines each of two populations (Wadi el Hassa and At Taibe) and of the check ER/Apm were sampled at anthesis stage in two replications in Hegla for proline analysis. The samples were ovendried at $70^{\circ} \mathrm{C}$. Pro- 
line content was determined according to WALDREN and TEARE (1974) with two replications of $0.02-0.05 \mathrm{~g}$ dry matter per sample, using a Beckman Model 25 spectro-photometer.

Germination tests: Germination trials were carried out using a germination chamber which provided constant $20^{\circ} \mathrm{C}$, light and high humidity. Germination containers with pleated filter papers which held 100 seeds were used. In Experiment 1: 25 lines were tested with a solution containing $300 \mathrm{mM} \mathrm{NaCl} / \mathrm{l}$. In each germination container, 20 seeds of five lines were placed. They were arranged as a $5 \times 5$ triple lattice design. Final germination counts were made after 14 days.

In experiment 2, five lines selected from the previous experiment were tested under-seven salt-concentrations: $0,100,150,200,250,300,350 \mathrm{mM} \mathrm{NaCl}$. The experiment had a split plot design with salinity level as main plots, and lines as subplots with three replications. Final germination counts were made after 14 days.

\section{Results}

Agronomic characterization under favourable conditions

The landrace lines when grown in Tel Hadia in $1982 / 83$, exhibited heading dates similar to the check varieties, with the lines originating from
Jordan and sourthern Syria being 1-3 days earlier and those from north-eastern Syria being $1-2$ days later. The population from Deir ez Zor, however, was 8-10 days later than all the other material (Table 2).

All landrace populations were significantly shorter than the six-rowed checks, but taller than the improved two-rowed checks. As observed on a larger sample of lines (WELIZIEN 1988), the southern material was significantly shorter than the northern populations, with the exception of the lines from Deir ez Zor.

The differences in straw quality between the landraces and check cultivars resulted in significantly higher lodging scores for the latter. Some differences between landrace populations were significant, supporting previous evidence (WELTZIEN 1988), which suggested that material from areas with higher productivity expectations showed reduced susceptibility to lodging. Similarly, the local check "Arabie Abied", which originated from very highly productive area, showed a significantly lower lodging score, than all other local material.

Total biological yield and grain yield for the majority of the landrace populations was lower than for the improved cultivars. However,

Table 2. Agronomic characteristics of eight landrace populations, when grown under favourable conditions in Tel Hadia, 1982/83

\begin{tabular}{|c|c|c|c|c|c|c|c|c|c|c|c|}
\hline Population & $\begin{array}{l}\text { Days to } \\
\text { heading } \\
\text { (d) }\end{array}$ & $\begin{array}{l}\text { Plant } \\
\text { height } \\
\text { (cm) }\end{array}$ & $\begin{array}{l}\text { Lodg- } \\
\text { ing } \\
\text { score }\end{array}$ & $\begin{array}{l}\text { Above } \\
\text { ground } \\
\text { biomass } \\
\text { (kg/ha) }\end{array}$ & $\begin{array}{l}\text { Grain } \\
\text { yield } \\
(\mathrm{kg} / \mathrm{ha})\end{array}$ & $\begin{array}{l}\text { Harvest } \\
\text { index }\end{array}$ & $\begin{array}{l}\text { Pro- } \\
\text { tein } \\
(\%)\end{array}$ & $\begin{array}{c}\text { Test } \\
\text { wt. } \\
(\mathrm{kg} / \mathrm{dt})\end{array}$ & $\begin{array}{l}100 \\
\text { grain } \\
\text { mass } \\
(\mathrm{g})^{-}\end{array}$ & $\begin{array}{c}\text { Seeds } \\
\text { per } \\
\text { head }\end{array}$ & $\begin{array}{c}\text { Heads } \\
\mathrm{m}^{2}\end{array}$ \\
\hline Madaba & 122 & 90 & 6.9 & 10140 & 4820 & 0.47 & 10.3 & 66.6 & 53.4 & 23.8 & 300 \\
\hline Wadi el Hassa & 120 & 91 & 6.5 & 10320 & 4940 & 0.48 & 11.3 & 66.8 & 57.9 & 23.0 & 427 \\
\hline Ras el Ain & 124 & 95 & 7.4 & 9210 & 3990 & 0.44 & 11.3 & 67.1 & 40.4 & 21.7 & 478 \\
\hline Sidnaya & 121 & 87 & 7.0 & 9030 & 4310 & 0.48 & 10.8 & 64.6 & 44.6 & 24.7 & $398^{\circ}$ \\
\hline At Taibe & 126 & 100 & 6.4 & 7800 & 3580 & 0.46 & 11.8 & 66.9 & 46.2 & 23.4 & 342 \\
\hline Sheikh Ali & 124 & 95 & 6.5 & 10680 & 5070 & 0.48 & 10.9 & 68.2 & 53.9 & 22.9 & 426 \\
\hline Deir ez Zor & 133 & 110 & 6.1 & 9500 & 3720 & 0.39 & 10.8 & 61.6 & 35.2 & 40.2 & 254. \\
\hline Um Zeitoun & 122 & 93 & 5.4 & 12050 & 5720 & 0.48 & 9.5 & 66.3 & 51.6 & 21.9 & 503 \\
\hline \multicolumn{12}{|l|}{ Checks } \\
\hline Beecher & 123 & 111 & 2.7 & 12160 & 5650 & 0.47 & 8.8 & 63.6 & 51.8 & 39.0 & 282 \\
\hline Badia & 124 & 115 & 3.9 & 12340 & 6020 & 0.49 & 9.5 & 64.8 & 52.8 & 48.5 & 236 \\
\hline ER/Apm & 124 & 73 & 1.0 & 10480 & 5460 & 0.52 & 9.3 & 67.3 & 46.3 & 21.6 & 548 \\
\hline Arabie Abied & 124 & 89 & 4.4 & 11350 & 5700 & 0.50 & 10.4 & 67.7 & .52 .9 & 20.4 & 530 \\
\hline Overall mean & 124 & 95 & 5.3 & 10200 & 4850 & 0.46 & 10.2 & 66.0 & 48.5 & 27.9 & 398 \\
\hline LSD $5 \%$ & 1 & 3 & 0.9 & 13503 & 652 & 0.016 & 1.2 & 1.1 & 1.4 & 2.3 & 53 \\
\hline
\end{tabular}


Table 3. Productivity of eight landrace populations under drought conditions, Breda 1983/84.

\begin{tabular}{lccccccccc}
\hline & $\begin{array}{c}\text { Total } \\
\text { dry } \\
\text { matter } \\
\text { Populations }\end{array}$ & $\begin{array}{c}\text { Grain } \\
\text { yield } \\
(\mathrm{kg} / \mathrm{h} / \mathrm{h})\end{array}$ & $\begin{array}{c}\text { Harvest } \\
\text { index }\end{array}$ & $\begin{array}{c}1000- \\
\text { grain } \\
\text { mass } \\
(\mathrm{g})\end{array}$ & $\begin{array}{c}\text { Seeds/ } \\
\text { head }\end{array}$ & $\begin{array}{c}\text { Heads/ } \\
\mathrm{m}^{2}\end{array}$ & $\begin{array}{c}\text { Days to } \\
\text { heading } \\
(\mathrm{d})\end{array}$ & $\begin{array}{c}\text { Plant } \\
\text { height } \\
\mathrm{cm}\end{array}$ & $\begin{array}{c}\text { Portion } \\
\text { of head } \\
\text { convered } \\
\text { by sheath }\end{array}$ \\
\hline Madaba & 2429 & 846 & 0.30 & 38.9 & 10.6 & 165 & 127 & 26 & 0.73 \\
Wadi el Hassa & 2630 & 933 & 0.31 & 37.5 & 12.0 & 161 & 127 & 25 & 0.57 \\
Ras el Ain & 2771 & 879 & 0.28 & 35.2 & 11.9 & 178 & 130 & 26 & 0.89 \\
Sidnaya & 2758 & 1044 & 0.33 & 33.9 & 13.1 & 183 & 126 & 25 & 0.45 \\
At Taibe & 2546 & 766 & 0.26 & 34.4 & 10.6 & 179 & 132 & 28 & 0.84 \\
Sheikh Ali & 2474 & 823 & 0.29 & 40.4 & 10.1 & 161 & 130 & 26 & 0.94 \\
Deir ez Zor & 2661 & 579 & 0.19 & 27.6 & 19.2 & 117 & 149 & 33 & 0.35 \\
Um Zeitoun & 2649 & 989 & 0.32 & 39.9 & 11.8 & 178 & 128 & 25 & 0.98 \\
Checks & & & & & & & & & 26 \\
ER/Apm & 2655 & 755 & 0.25 & 31.9 & 14.6 & 136 & 129 & 26 & 0.46 \\
Badia & 3037 & 678 & 0.20 & 38.9 & 15.6 & 93 & 132 & 30 & 1.68 \\
Overall mean & 2620 & 854 & 0.28 & 35.9 & 12.5 & 163 & 131 & 28 & 0.71 \\
LSD 5 \% & 253 & 67 & 0.02 & 1.6 & 1.2 & 20 & 2 & 1 & 0.15 \\
\hline
\end{tabular}

highly significant differences between populations were observed, with the two populations from higher productive areas showing yield levels similar to the checks (Table 3). The harvest index of the landrace populations showed only few differences from the improved cultivars, which is remarkable, since cereal landraces from Europe generally have very low harvest indices (AurEAAMMER and FIsCHBECKS 1964).

Most of the landraces had significantly higher grain protein percentage then the improved cultivars. However, little variation among population means was observed. The mean test weights for the two-rowed populations showed little significant deviation from the two-rowed check cultivars, however there were significant differences among population means.

The separation into the three yield components, 1000 grain mass, grains/head, heads $/ \mathrm{m}^{2}$, showed significant differences for all three components among the population means (Table 2). The material from the wetter areas showed significantly higher 1000 grain weights.

\section{Productivity under dry conditions}

The severe drought in the 1983/84 season resulted in an overall severe growth reduction at
Breda (Table 3). However, for all traits, significant differences between the populations and the check cultivars, as well as among the populations were observed. Most of the landrace populations outyielded the checks significantly, indicating better adaptation to drought conditions. The higher grain yield of the landrace lines was mainly due to higher numbers of seeds per head, but tillering also contributed to their yield advantage (Table 4).

In all of the material, difficulties with head extrusion were observed (Table 3), with large variations among the population means. Higher seed set was associated significantly with good head extrusion $(r=-0.41, \mathrm{P}<0.05)$.

\section{Productivity under dryland salinity}

Yields in Hegla in 1982/83 reached levels comparable to those in Breda in 1983/84 (Table 5). Generally, however, the yield component

Table 4. Correlations of the yield components with grain yield at the three locations (line mean basis)

\begin{tabular}{lccc}
\hline & $\begin{array}{c}\text { 1000-grain } \\
\text { mass }\end{array}$ & $\begin{array}{c}\text { No. seeds/ } \\
\text { head }\end{array}$ & $\begin{array}{c}\text { No. heads/ } \\
\mathrm{m}^{2}\end{array}$ \\
\hline Tel Hadia & $0.59^{* * *}$ & -0.18 & $0.67^{* *}$ \\
Breda & $0.53^{* *}$ & $0.53^{* * *}$ & $0.33^{*}$ \\
Hegla 1982/83 & $0.43^{* *}$ & $0.61^{* *}$ & $0.77^{* *}$ \\
\hline
\end{tabular}


Table 5. Productivity of eight landraces populations under saline conditions, Hegla 1982/83, 1983/84

\begin{tabular}{|c|c|c|c|c|c|c|c|c|}
\hline \multirow[b]{2}{*}{ Populations } & \multicolumn{6}{|c|}{ Hegla 1982/83 } & \multicolumn{2}{|c|}{ Hegla 1983/84 } \\
\hline & $\begin{array}{c}\text { above } \\
\text { ground } \\
\text { dry matter } \\
\left(\mathrm{g} / \mathrm{m}^{2}\right)\end{array}$ & $\begin{array}{l}\text { grain } \\
\text { yield } \\
\left(\mathrm{g} / \mathrm{m}^{2}\right)\end{array}$ & $\begin{array}{c}\text { harvest } \\
\text { index }\end{array}$ & $\begin{array}{l}\text { heads/ } \\
\mathrm{m}^{2}\end{array}$ & $\begin{array}{l}\text { seeds/ } \\
\text { head }\end{array}$ & $\begin{array}{l}1000 \\
\text { seed } \\
\text { mass } \\
(\mathrm{g})\end{array}$ & $\begin{array}{c}\text { above } \\
\text { ground } \\
\text { dry matter } \\
\left(\mathrm{g} / \mathrm{m}^{2}\right)\end{array}$ & $\begin{array}{c}\text { grain } \\
\text { yield } \\
\left(\mathrm{g} / \mathrm{m}^{2}\right)\end{array}$ \\
\hline Madaba & 225 & 109 & 0.49 & 255 & 9.6 & 42.7 & 60 & 27 \\
\hline Wadi el Hassa & 217 & 108 & 0.50 & 265 & 9.9 & 40.2 & 67 & 33 \\
\hline Ras el Ain & 193 & 93 & 0.49 & 269 & 8.6 & 38.8 & 41 & 14 \\
\hline Sidnaya & 244 & 125 & 0.52 & 307 & 10.8 & 37.9 & 45 & 21 \\
\hline At Taibe & 193 & 92 & 0.48 & 231 & 9.1 & 36.6 & 50 & 19 \\
\hline Sheikh Ali & 249 & 128 & 0.52 & 296 & 9.4 & 44.1 & 63 & 27 \\
\hline Deir ez Zor & 173. & $81-$ & $0: 46$. & 172 & 14.8 & 31.4 & 29 & 7 \\
\hline Um Zewitom & 221 & 112 & 0.50 & 294 & 9.1 & 40.7 & 58 & 26 \\
\hline \multicolumn{9}{|l|}{ Checks } \\
\hline ER/Apm & 137 & 74 & 0.54 & 204 & 9.8 & 36.7 & 14 & 5 \\
\hline $\mathrm{CM} 67$ & 115 & 56 & 0.48 & 153 & 10.2 & 34.6 & 11 & 3 \\
\hline Overall mean & 212 & 105 & 0.49 & 234 & 10.1 & 37.9 & 40 & 17 \\
\hline LSD $5 \%$ & 21 & 10 & 0.13 & 2 & 0.6 & 1.1 & 23 & 13 \\
\hline
\end{tabular}

structure was different: grain yields were achieved through higher numbers of fertile tillers and higher grain weight, rather than high seed set. The differences in biomass and grain yield between the two-rowed landraces and the checks were more pronounced than in Breda; with the latter showing much reduced tillering ability "under saline conditions. Population means also varied significantly, with the populations from the rather productive areas of Sheikh Ali and the Anti-Lebanon mountains near Sidnaya showing the highest means for grain yield and biomass.

In $1983 / 84$ the productivity was reduced to one fifth of the previous year and the superiority of the landrace material over the check cultivars was more pronounced than previously (Table 5). However, only few of the comparisons among population means were significant for grain yield and biomass.

\section{Genetic variation among and within popula- tions under stress}

The analysis of variance, subdividing the variance among entries. into a component due to differences among populations and one due to differences among lines within populations, showed significant mean squares for all traits except one. The two variance components esti- mates (Table 6) at both locations were of similar magnitude for grain yield. For the three yield components, however, the component resulting from differences among populations

Table 6. Estimates of genotypic variances for grain yield and its components among and within populations of barley landraces, when tested in Breda 1983/ 84, and Hegla 1982/83/84

\begin{tabular}{lrrrr}
\hline Trait/location & $s_{\text {pop }}^{2}$ & $s_{1(p o p)}^{2}$ & $s_{\text {error }}^{2}$ & $\mathrm{~h}^{2 * * * *}$ \\
\hline $\begin{array}{l}\text { Grain yield } \\
\quad\end{array}$ & & & & \\
$\quad$ Breda & 188.9 & 102.0 & 166.5 & 0.65 \\
Hegla & 193.5 & 228.1 & 1165.4 & 0.66 \\
Heads/m & & & & \\
$\quad$ Breda & 370.0 & n.s. & 1421.8 & 0.00 \\
Hegla & 1398.7 & 1242.4 & 5719.5 & 0.68 \\
Seeds/heads & & & & \\
Breda & 7.6 & 0.9 & 4.7 & 0.32 \\
Hegla & 2.3 & 0.9 & 4.8 & 0.55 \\
1000 seed mass & & & & \\
Breda & 10.9 & 3.5 & 7.3 & 0.59 \\
Hegla & 15.2 & 4.0 & 35.9 & 0.60 \\
\hline
\end{tabular}

$* s_{\text {pop }}^{2}$ : variance between populations

$\because s_{1(p o p)}$ : variance between lines within populations

*:- $\mathrm{h}^{2}$ : heritability on a line mean basis 
was generally much higher than the within populations component. The heritabilities on an entry mean basis (Hallauer and Miranda 1981), achieved through the respective field designs (Table 6), are in a satisfactory order of magnitude for the selection among populations, as well as selection within populations at each site. The phenotypic correlations for grain yield in the different environments were in most cases significant (Table 7), but low, indicating that high genotype by environment interactions are present in this material for these sites. Therefore, the selection environments should carefully be chosen to match the expected growing conditions for new potential varieties.

Table 7. Correlations between grain yields for the four experiments, on a line-mean basis

\begin{tabular}{lccl}
\hline & $\begin{array}{c}\text { Breda } \\
83 / 84\end{array}$ & $\begin{array}{c}\text { Hegla } \\
82 / 83\end{array}$ & $\begin{array}{l}\text { Hegla } \\
83 / 84\end{array}$ \\
\hline T. Hadia 82/83 & $0.36 * *$ & $0.27^{*}$ & $0.28 *$ \\
Breda 83/84 & - & 0.25 & 0.17 \\
Hegla 82/83 & & & $0.32 * \%$ \\
\hline
\end{tabular}

$*$ significant at $\mathrm{P}<0.05$

$* *$ significant at $P<0.01$

\section{Flagleaf proline content}

The flagleaves of lines from two landrace populations, both originating from dry areas, showed significantly different amounts of pro-

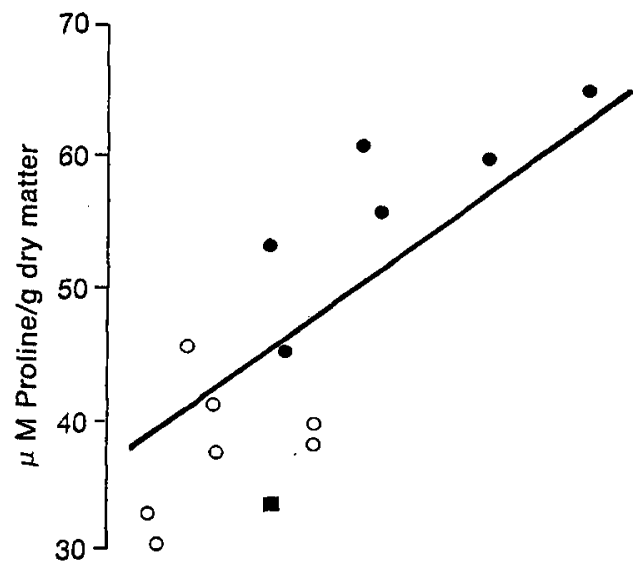

- Wadi el Hassa

- At Taibe

ER/Apm

$\begin{array}{lllll}7.0 & 9.0 & 8.0 & 10.0 & 11.0 \mathrm{dt} / \mathrm{ha}\end{array}$

Grain yield in Breda 1983/84 lin accumulated per unit dry matter (Fig. 2). Both populations had higher proline contents than the 2-rowed check ER/Apm. The proline content, measured under severe drought and salinity stress, correlated well with grain yields obtained under drought conditions (Fig. 2).

\section{Germination responses}

In experiment 1, 15 of the 21 landrace lines tested showed very low germination compared to the checks and six landrace lines (Fig. 3). In the second expériment, one of the sensitive lines showed this sensivity also at very low salt concentrations (Fig. 4): There was no relationship between the germination response in $\mathrm{NaCl}$-solutions and the plant stand, grain and straw yield performance under saline field conditions of these lines.

\section{Discussion}

One important result of this agronomic evaluation of a small sample of homozygous landrace lines is their superiority over introduced and improved cultivars, when tested in high stress environments in the area, where these landraces have been collected. This is in part surprising, as the landrace lines are a random sample from a large collection and have not undergone any methodical selection for yielding ability, in contrast to the checks used in this study (MEKN 1981). 'The good adaf' tion of these landraces to the growing condicions 
Fig. 3. Germination percentage after 14 days of 25 barley lines in saline solution of $300 \mathrm{mM} \mathrm{NaCl}$

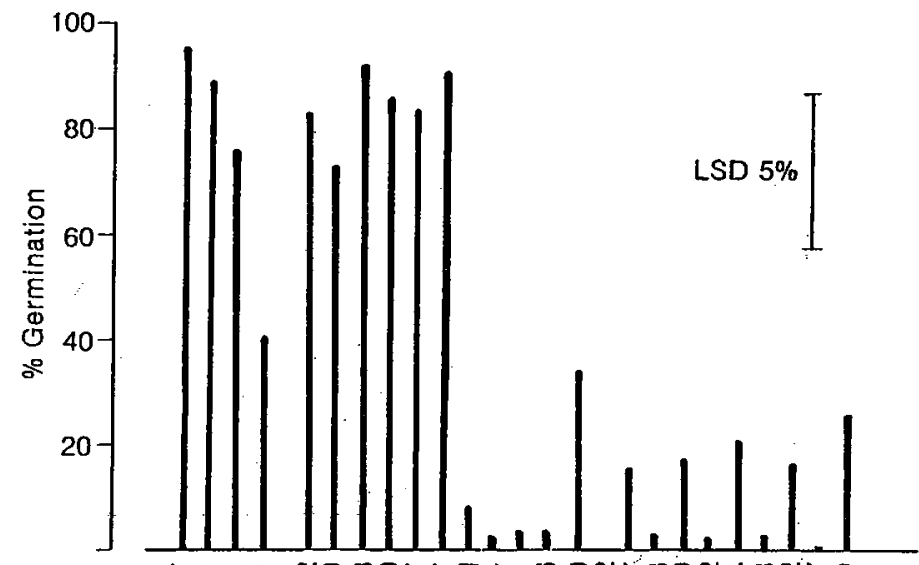

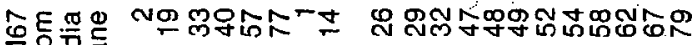

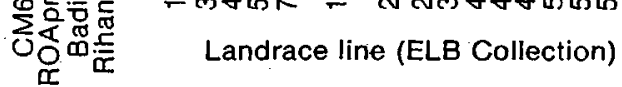
픈 Controls

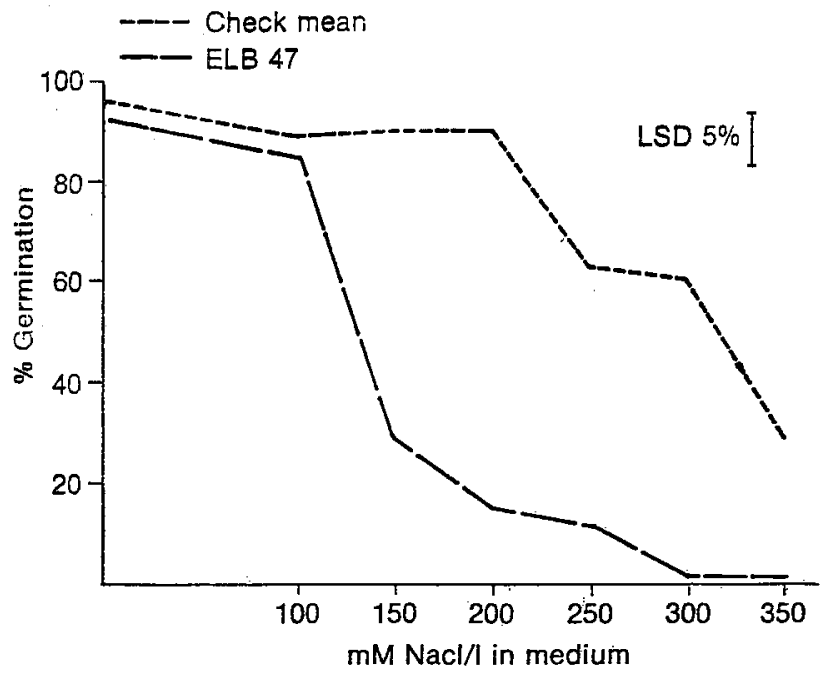

Fig. 4. Germination percentage after 14 days for landrace line ELB 47 and the mean of Badia, ER/Apm, ELB 58 and ELB 79 under increasing salt concentration

studied is furthermore indicated by its high, near-optimum, harvest index in most cases. This implies that further genetic improvement cannot rely on raising the harvest index, but improvement of total biomass productivity has to be achieved. The tremendous variation found in this limited sample of landraces for straw and grain yield and their components offers good expectations for a first cycle of selection. It suggests that direct selection between population and between lines from superior populations is a valid approach to the development of cultivars with higher yielding ability under these stress conditions and good responsiveness 'to productive - environmen'ts. CECCARELLI et al. (1987a) found similarly high genetic variances testing a larger sample of these lines at one location. Recent advances further show, that this material constitutes a valuable resource for the improvement of barley production in the eastern mediterranean region (ICARDA 1988).

Stress environments with low yield potential are frequently not recommended as iselection sites, because grain yield and related traits show lower heritabilities (QUISENBERRY et al. 1980, Shabana et al. 1980) than under optimum conditions. The heritabilities measured 
in this study were, however, in a satisfactory range, and indicate that successful varietal comparisons can be made at Breda and in better years in Hegla. The usefulness of a selection environment furthermore depends on the correlation of the results achieved there with those in the target environment for the new varieties (FALCONER 1952). Based on these relationships, ATLIN and FREY (1989) found that, even within the American Midwest, low productivity environments may be the best selection environments for oat varieties targeted for such conditions. Considering, thus, the correlations of $0.27-0.36$ found between the results at Tel Hadia with Breda and Hegla, compared to $0.66-0.95$ in ATIrN and

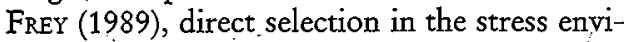
ronment is expected to be superior for improving barley for the Syrian steppe. Selection experiments in Breda and Tel Hadia with segregating material (CECCARELLI et al. 1987b) support this conclusion. Similarly, the finding that the landraces, which developed under these low productivity conditions through natural selection and selection by the local farmers, yielded comparatively well there, indicates the usefulness of the steppe area as a selection environment.

In this material significant associations with grain yield under drought conditions (Breda) were observed for earliness $(r=0.36)$, narrow leaves $(r-0.63)$ and prolin content in the flagleaves of extremely stressed plants ( $r$ 0.78 ). Crop physiologists frequently consider these three traits important for optimizing water use and, hence, grain yield for cereals in mediterranean environments (Richards 1987). They have been recommended as selection criteria for breeding programs working in drought prone environments of this type. Usually such trait associations observed in breeders nurseries or yield trials do not allow widely applicable conclusions about the usefulness of selecting for such secondary traits, because the variety "or lines tested differ greatly in their genetic background. These differences in genetic background normally confound associations observed between traits. The material tested in this study can be assumed to be rather undisturbed landrace material and, thus, in a broad or evolutionary sense as being near isogenic populations (LANGLET 1971): Under this assimption these trait associations indicate that these traits are valuable for improving barley grain yield and stability in the described environment.

In this context the germination behaviour observed in this material may also be relevant. It could be the result of natural selection against germination under conditions of insufficient water supplies in the soil to support the emerging seedling. Such conditions occur frequently in Northern Syria, where planting is done before the onset of the winter rains. Such high sensitivity to osmotic stress could protect material from germinating with the first erratic rains. The value of these traits as selection criteria, however, will need more in depth study.

The advantages of using landrace material for such preliminary studies of traits with an adaptive advantage for a particular drought. environment, are that they are immediately available to serve as breeding material, and offer comprehensive insight into possible adaptations to a particular farming system. These studies, however, are only relevant in areas lying within the primary and possibly secondary center of diversity of the crop under study.

\section{Zusammenfassung}

Leistung und Variabilität von Landsorten der Gerste in Umwelten des Nahen Ostens

Homozygote Linien aus sechs syrischen und zwei jordanischen Landsorten-Populationen wurden unter günstigen Bedingungen in Tel Hadia (1982/83), unter Dürre in Breda (1983/ 84) und auf versalzten Flächen in Hegla (1982/ $83 / 84$ ) in Syrien geprüft. Die Versuchsmittel für den Kornertrag schiwankten zwischen 260 und $4850 \mathrm{~kg} / \mathrm{ha}$. Unter dem Einfluß von Dürre und Versalzung erbrachte die Mehrheit der Landsorten signifikant höhere Erträge als die Kontrollsorten. In Tel Hadia waren die Kontrollsorten überlegen, jedoch nicht immer signifikant. An allen Standorten zeigten die Landsorten einen nahezu optimalen ErnteIndex. Pflanzenhöhe und Blühzeitpunkt dieses Materials waren intermediär. Es zeigte weiterhin eine hohe Lageranfälligkeit unter günstigen Bedingungen, einen hohen Proteingehalt und sehr unterschiedliche Kombinationen der Ertragskomponenten. 
In Breda und Hegla waren die genetischen Unterschiede zwischen den Linien hochsignifikant. Die operativen Heritabilitäten waren ebenfalls hoch. Die Korrelationen zwischen den Ertragsleistungen der Linien an den verschiedenen Standorten waren niedrig. Daher sind die besten Selektionsgewinne bei der Sortenentwicklung für die Syrische Steppe bei direkter Selektion unter Streßbedingungen $\mathrm{zu}$ erwarten.

Weitere Besonderheiten der Landsorten beobachteten wir bei der Prolin-Akkumulation und bei Keimversuchen in Salzlösungen. Somit konnten in dieser Untersuchung eine Serie von Beobachtungen zusammengefaßt werden, die die Benutzung dieses Materials in der dortigen Gerstenzüchtung nahelegen.

Prof. Dr. W. Huber and Mrs. S. STAILENBerger provided laboratory facilities and guidance in conducting the protein analysis. We thank them for their support and interest in this study. We thank Dr. J. P. SRIVASTAVA (ICARDA) for his continued support for conducting the field expriments. Thanks are also due to Mr. HAMADE SHEIHK for providing the testing facilities in Hegla; the ICARDA Farming Systems Program for providing the plots in Breda; the Quality laboratory for conducting the protein analyses; to the genetic ressources unit for providing the facilities for the germination trials; and to the barley breeding "groups for helping in many unforeseen ways anytime.

\section{References}

AtLIN, G. N., and K. J. FrEY, 1989: Predicting oat yield gains in low-productivity environments from selection under low-, medium-, and high-productivity conditions. Euphytica. In Press.

AUFHAMMER, G., and G. FISCHBECK, 1964: Ergebnisse von Gefäß- und Feldversuchen mit dem Nachbau keimfähiger Gersten- und Haferkörner aus dem Grundstein des 1832 erbauten Nürnberger Stadttheaters. Z. Pflänzenzüchtg. 51, 354-373.

CECCAREIII, S., S. GRando, J. A. G. VAN LeUR, 1987: Genetic diversity in barley landraces from Syria and Jordan. Euphytica 36, 389-405.

-- M. M. NAChIT, G. O. Ferrara, M. S. MEKNI, M. TAHIR, J. VAN LEUR, and J. P. SRIVASTAVA, 1987: Breeding for cereal yield and stability under drought. In: SRIVASTAVA, J. P., E. ACEVEDO, and S. Verma (eds:), Drought Tolerance in Winter Cereals, pp. 101-114. Chichester: John Wiley.
FALCONER, D. S., 1952: The problem of environment and selection. Am. Natur. 86, 293-298.

FAO, 1987: 1986 Production Yearbook. Rome.

FEDERER, W., 1961: Augmented design with oneway elimination of heterogeneity. Biometrics 17, $447-473$.

Hallauer, A. R., and J. B. Miranda Fo., 1981: Quantitative Genetics in Maize Breeding. Iowa State University Press, Ames, Iowa, USA.

ICARDA; 1981: Data on the Classification and the Fertility of Soils at Khanasser, Breda, Tel Hadia, Kafr Antoon and Jindiress. Aleppo, Syria.

_,, 1984: Annual Report 1983. Aleppo, Syria.

- _, 1988: Cereal Improvement Program. Annual

Report for 1987, pp. 24-28. Aleppo, Syria.

LANGLET, O., 1971: Two hundred years gene ecology. Taxon 20, 653-722.

MEKNI, M. S., 1981: Barley breeding at ICARDA for North Africa and West Asia regions. In: Proc. 4th Int. Barley Genetics Symp. Barley Genetics IV, pp. 362-371. Edinburgh.

QUISENBERRY, J. E., B. ROARK, D. W. FREYREAR, and R. J. KOHEL, 1980: Effectiveness of selection in upland cotton stress environments. Crop. Sci. 20, $450-453$.

RICHARDS, R. A., C. W. DENETT, C. O. QuAISET, E. EDSTEN, J.D. NORLYN, and M. D. WINSIOW, 1987: Variation in yield of grain and biomass in wheat, barley and triticale in a salt-affected field. Field Crops Research 15, 277-287.

SHABANA, R., T. BAILEY, and K. J. FReY, 1980: Production traits of oats selected under low, medium, and high productivity. Crop Sci. 20, 739-744.

Waldren, R. P., and I. Teare, 1974: Free proline accumulation in drought stressed plants under laboratory conditions. Plant and Soil 40, 689-692.

WAITER, H., und H. LIETH, 1981: Klimadiagramm Weltatlas. Jena: VEB G. Fischer.

WELIZIEN, E., 1982: Barley collection and evaluation in Syria and Jordan. Plant Gen. Res. Newsl. 51, 13-14.

- -, 1986: Anpassungsfähigkeit nahöstlicher Landgersten an marginale Wachstumsbedingungen. Dissertation. TU München, Freising-Weihenstephan.

- -, 1988: Evaluation of barley (Hordeum vulgare L.) Landrace populations originating from different growing regions in the near east. Plant Breeding 101, 95-106.

WIRTH, E., 1971: Syrien. Eine wissenschaftliche Länderkunde. Darmstadt: Wiss. Buchges.

Authors' addresses: Dr. E. WELTZIEN, ICRISAT, PMB, Patancheru P.O., A.P., 502324 (India); Prof. Dr. G. FISCHBECK, Lehrstuhl für Pflanzenbau und Pflanzenzüchtung, T.U. München, D-8050 Freising-Weihenstephan (Germany, F.R.). 